\title{
EDITING GENES TO BENEFIT SICKLE CELL DISEASE PATIENTS
}

\author{
DR NATALIA RIVERA-TORRES IS CONDUCTING SICKLE CELL RESEARCH \\ AT THE CHRISTIANACARE'S GENE EDITING INSTITUTE IN DELAWARE \\ IN THE US. THE INSTITUTE IS AN ASPIRATIONAL AND SUPPORTIVE \\ COMMUNITY COMPOSED OF PEOPLE AT DIFFERENT STAGES OF THEIR \\ CAREER - ALL OF WHOM DO GROUND-BREAKING WORK
}





\section{HOW DID NATALA BECOME A GENE EDITOR?}

WHAT WERE YOUR INTERESTS AS A CHILD?

As a child, I was heavily involved in music and the performing arts to the extent that I contemplated becoming an opera singer! But I was also very intrigued in science and biology, which maybe started when my parents got me a red microscope for my 7 th birthday. As I grew older, the more fascinated I became with the new discoveries in biology and music became more of a hobby.

WHO OR WHAT INSPIRED YOU TO BECOME A SCIENTIST?

I was exposed to science from a young age through my father who is a physiologist and had a research lab of his own. As a kid, I would spend time in his lab, wanting to play and experiment with all the interesting things in there. I became fascinated by the concept of experimentation to find results to questions and it opened the door of understanding that there was an infinite number of things that we had no answers to, and that it was through science that those answers would be found. As I grew older, and the more I learned biology in school, the more molecular biology and genetics appealed to me.

WHAT ATTRIBUTES HAVE MADE YOU A SUCCESSFUL SCIENTIST?

I am a hard worker who is passionate about the projects I take on - I like to see them completed, regardless how challenging they might be. I am not afraid to learn new techniques and am aware I do not know everything; I recognise what I am not so good at and am open to asking for help and collaborating with people who are better in those areas. I also consider myself humble and approachable to those around me who might need assistance.

\section{WHAT ARE YOUR PROUDEST CAREER} ACHIEVEMENTS?

The day I successfully defended my PhD thesis - that was a major life accomplishment! Publishing my first paper as a first author was also a highlight.

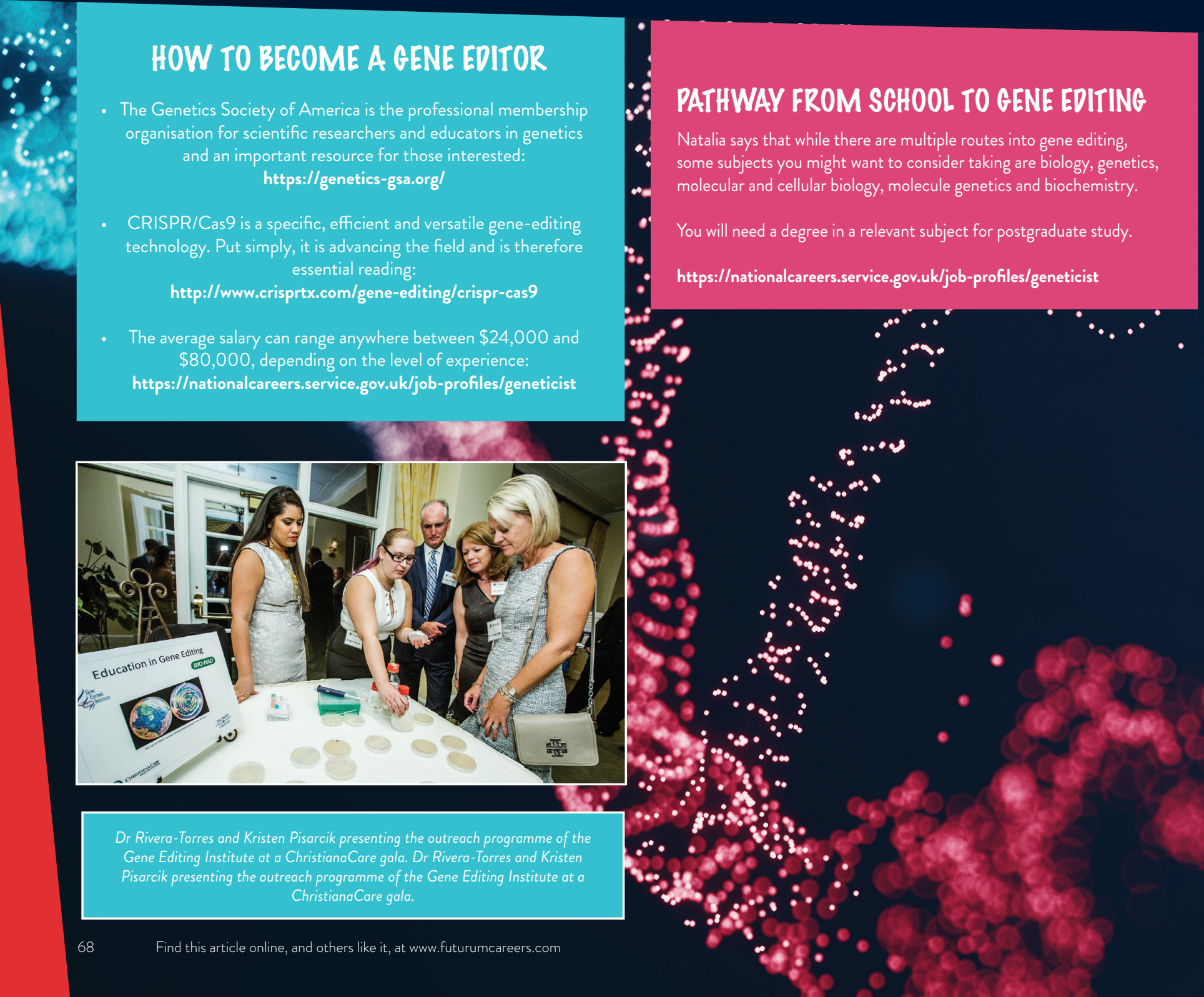




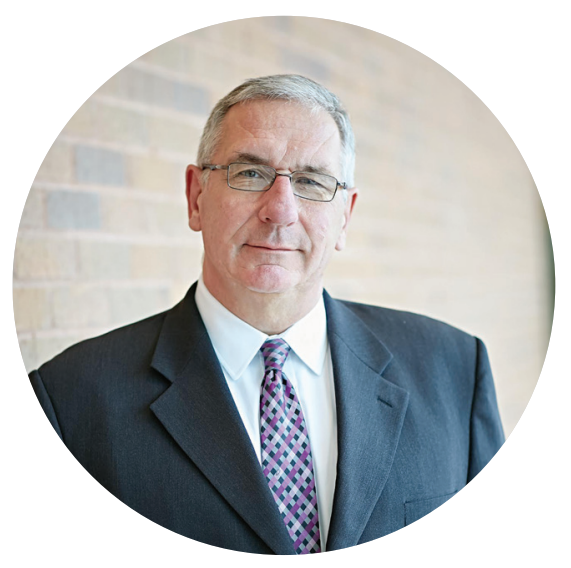

Dr Eric Kmiec is the founder and director of ChristianaCare's Gene Editing Institute. His research centres on understanding the process of gene repair and gene editing with a focus on CRISPR-directed genome engineering in human cells.

I grew up in a very blue-collar town and neighbourhood and neither of my parents went to college. I am most proud of that because it taught me to work hard and to never forget my roots.

As a student, I was pretty good. My best subjects were probably biology and American history. I was a fanatical butterfly catcher, capturing them, mounting them in small frames and providing them as gifts at Christmas.

My father was insistent that I focus hard on my studies and so I think he was my first inspiration. He worked at Monsanto in the pilot plant

\section{PROFILE: ERIC KMIEC, PH.D.}

without ever earning a college degree. Kathy Dorey, Ph.D., at Southern Illinois University stands out as someone who showed me what an academic life could be like.

There is no question that relentless dedication, intense hard work and never giving up on your ideas and dreams is at the centre of success. But, it is equally important to recognise when you are chasing a hallucination - self-reflection is gained through lifelong learning and experience and being observational rationale and truthful about yourself.

I have been able to craft innovative ideas on how genes could be repaired in mammalian cells. This was the result of attaining and using a strong background in the molecular biology of recombination and repair processes, and understanding the cellular mechanisms that repair DNA.

It was very tough in the early years of gene editing as most workers in the field of gene therapy did not believe gene editing or gene correction would ever work. There were only a handful of scientists in the field and the potential of our work with not taken very seriously. I am proud that we kept going, fought uphill and sustained our ideas, despite a lot of early criticism that we were not only wrong but fanciful.

The CRISPR tool has allowed us to increase the frequency with which we repair genes and increase the precision with which we disable them. While none of the basic reactions of gene editing are new, and some parameters we identified ourselves years ago, CRISPR allowed us to pinpoint where we want to make these changes in a much more precise and efficient fashion.

It was a big moment when we were first able to use synthetic single-stranded DNA templates to correct the point mutation in a mammalian cell. These are experiments conducted in a model system in which the cell was colourless until the targeted gene was corrected, and then it turned green.

In those early days, there were probably only two cells out of a thousand that were green, but they grew and expanded, and we were thrilled to see them appear. When my graduate student, Brett Sansbury, Ph.D., developed the system and was able to do gene editing on a chip, it was fantastic and something I had always dreamed of.

Now is the most exciting time to be a geneticist and for young people to choose to study gene editing. With the molecular toolbox created by our generation, and the imagination and computational skill set of our younger generations, the possibilities are simply endless. Excellent technological developments, with a serious dose of humanity and ethics, is what the next generation will have to deal with, but I am confident they will do so intelligently.

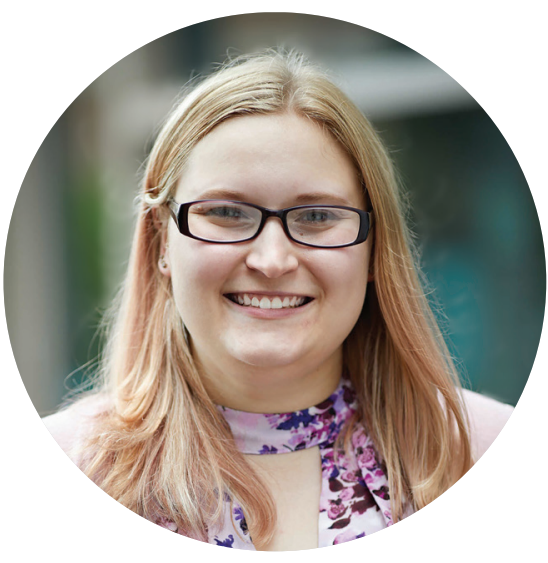

Kristen Pisarcik is a research assistant and science educator at ChristianaCare's Gene Editing Institute.

As a child, science and photography were my primary interests. I have always enjoyed biology, specifically marine biology, astronomy, and archaeology. I was also interested in anything art-related but enjoyed photography and knitting the most.

\section{PROFILE: KRISTEN PISARCIK}

I remember I got my hands on a book about all the different kinds of dolphins and whales in the world and, from that moment on, I knew I was going to do some sort of biology. Most of my inspiration came from reading books that contained as much information as I could digest.

I started working at the Gene Editing Institute as a student at Delaware Technical Community College doing undergraduate research. After graduation with my associate degree, I continued to work with them on a grant. Currently, I am pursuing my bachelor's degree, with hopes to complete my master's and maybe a doctorate.

My role is to listen in to all the research being done in the lab and then think about ways that this high-level science could be converted into curriculum for students at any level. This includes materials as well as potential laboratory exercises.
The most challenging and rewarding part of this is definitely taking the complicated science and making it understandable and accessible to students and the general public.

My role requires collaboration on every level. I am commonly talking to students, to teachers (at all levels), or to foundations/companies/ organisations. I have learned that this role is based on the collaboration and feedback of others.

I have many ambitions for the future. I hope to reach as many students, in as many backgrounds, with as many levels of education as possible, to talk about gene editing and science in general. If I can spark an interest in science in any student, I will be happy. I also hope to be able to work on a gene editing project that leads to a cure or therapy for a disease - I think that would be something really cool to contribute to! 